\title{
Research on Farmers' Mechanism for Interests Expression in the Construction of New Socialist Countryside
}

\author{
Jiapeng Dai ${ }^{1, a}$, Chenglong Sun ${ }^{2, b,{ }^{*}}$ and Lu Yang ${ }^{3, c}$ \\ ${ }^{1}$ College of Economics and Politics, Shaanxi Normal University, China \\ ${ }^{2}$ Faculty of Economics and Management, University Putra Malaysia, Malaysia \\ ${ }^{3}$ Law School, Beijing Normal University, China \\ adai854148@163.com, bsunscl@masn.cn, cvictoria_yl@126.com \\ *The corresponding author
}

Keywords: The construction of new countryside; Mechanism for interest expression; The integration of urban and rural areas; The grassroots democracy

\begin{abstract}
Urbanization and industrialization accelerated the pace of China's economic and social development, bring us improvement of the comprehensive national power and total economic quantity, the construction of new socialist countryside has become the basic way to solve the problem of agriculture, rural areas and farmers, which is also a basic task of national social development that our new era gives. Farmers' interest expression is the first step of the government process, reflects the degree of the understanding of public opinion, and then influences construction of democracy at the grassroots level. This paper, on the background of construction and development of new countryside, points out the significance of construction of new countryside, and gives theoretical analysis of the "contradiction between people and officer" in the light of mechanism for interest expression that occurs in the construction of new countryside. Exploring the reasons from 3 perspectives of interest expression: subjectivity, objectivity, and its external environment, then put forward improvement suggestions to the dilemma of current farmers' interest expression from the aspect of national level, social level and individual level.
\end{abstract}

\section{Introduction}

Since China has been established, the main power of its economic development comes from agricultural surplus. The development strategy of industrialization makes county's construction center of gravity on primary industry, which agriculture provides significant fund support to industry. In order to relieve the contradiction between primary industry and secondary industry that the former one develops too fast and the later one lack of dynamic, China puts forward concept of the construction of new socialist countryside after it experienced the first "Five Year Plan".

Chew Rosalind and Chew SOON-BENG believe that traditional era of planned economy has caused the situation of famer's interest rigidified, the expression mechanism of public opinion is also destroyed seriously. [1] However, since Reform and Opening, our party and country has made new plan on the future development of countryside based on the past experience. The first point of the construction of new socialist countryside lies in developing agriculture and revitalizing rural economy, especially improving security of farmers' basic living condition, liberating and developing rural productivity. Rowley, Timothy I, Moldoveanu, Mihnea. put forward that because of rigescent system and poor execution power, absence of fundamental organization function and phenomenon of administrative behavior deviation has appeared. [2] Although the construction of new socialist countryside has achieved certain effect, a serious of problems are thereupon spring up, and then influence construction of harmonious society and new socialist countryside.

Three agricultural problems are core issues related to people's living conditions, which reflect determination of deepening socialist reform of our party and country. At present, our main task is dealing with the relationship between government and market, mobilizing the positive factor to resolve 
three agricultural problems. Harrington, Catherine B hold the view that China should alter unskillful cultivation method in the past time, and bring in advanced machine to develop modern intensive agriculture. [3] Protecting farmers' interest when implementing land expropriation system, adhering to the principle of "Farmland for farming". What's more, government should not violate farmers' land illegally.

Benefit is the dynamic source people engage in production and life, because of which our society are connected with each other, and then become the most active factor in market economy. As Halbach Jr., Edward C says, the expression of farmers' interest embodies strong wish of maintaining their own interest. They live in grass-roots society and share limited social resource, if fundamental political right can't be guaranteed, expression mechanism of farmers' interest might not achieve breakthrough outcome. [4] Thus, perfect expression mechanism is the source of building new countryside and necessary choice of facilitating integration of city and countryside.

\section{Situation and Diploma in the Construction of Expression Mechanism of New Socialist Countryside.}

This part can be depicted as three aspects. Firstly, The contradiction between rationality of farmers' interest expression and imperfection of laws as well as regulations. Farmers' interest expression is the significant method for them to participate in democratic management, express politic desire, exercise fundamental right that conferred by the constitution. Because of some irresistible factors such as policy-implementation deviation and administrative action deviation of government, construction of new countryside confronts pressure of local authority. Basic-level organization and farmers' autonomous organization gradually developed as subordinate organ because lack of public power, so farmers request for proper interest via reflecting their interest appeal to government possess realistic rationality, by which they can maintain basic living and developmental right.

With the development of urbanization in China, the construction of new socialist countryside is conferred with new times connotation. The phenomenon that peasants' interest is invaded is common in the process of government implementation. Compared to local government, peasants group is obviously in the negative position, they have little knowledge about policy and regulation of our country, thus, they have no choice when confronting non-normative behavior. The power constraint mechanism is not sound in the construction of new countryside in China, even not form a system of legal mechanism, which makes local power in a state of "vacuum". [5] The perfect degree of laws and regulations represents the level of legal system of a country, only there are laws to abide by can achieve the requirement of acting by law. There are only macroscopic regulations for rural development in the new countryside construction, the lack of law execution details provides chances for part of the civil servants whose administrative ethics level is not high. In addition, in order to drive the development of GDP, they loot farmers land wealth wantonly to win local performance. Farmers' interest expression has the rationality that the constitution confers on, but it is damaged by the offside and omission of local government function because unsound of laws and regulations, and then farmers normal interest expression conduit is put off. [6]

Secondly, the contradiction between farmers' strong desire for expressing opinions and singleness of expression conduit. The new countryside construction means to bring in urban management way to rural to a certain extent, and exercise the development mode that city leads rural and industry compensates agriculture. The existence of land expropriation is inevitable in new countryside construction. Land acquisition system can be said to be the most serious crux of farmers' interest damage at this stage. Land is the material basis for survival, however, for the sake of achieving performance quickly and effectively, local government generally start from constructing buildings in the new rural construction, collecting the original land even normal arable land used for building community. This disguised land expropriation behavior which is euphemistically called "construction of new countryside" has seriously influenced the normal production and living, farmers basic interest is violated, and thus have a strong desire to express interests. 
At present farmers' interest expression channels is single in our country, in addition to the rural residents' committees conference that can select farmers for deputy to the NPC, there are almost no other formal channels. Rural residents' committees are controlled of grassroots government workers, who hold the content of the conference ahead of time, the real meeting is just "go through the motions". [7] Many important decisions have been confirmed before the meeting, listening to public opinion is just a bluff. Farmers also has a lot of limitations as a representative of the National People's Congress, for example, the elected farmers are generally recommended by the government, most of the time is not on behalf of the farmers but become a spokesman for the maintenance of local government image; What's more, the voice of National People's Congress is also very limited to farmers, and it is still some professional representatives and representatives of the government plays a part ultimately, peasants seem to be the "puppet" under democratic society. The real public opinion cannot get effective appeal. Farmers' interest expression channels in our country is too single, there is no chance to speak to farmers, while farmers are full of words of interest appeal. This strong voice of primary-level government under pressure type system has hindered channels of public opinions, which causes to political tragedy of farmers "collective aphasia". [8]

Lastly, the contradiction between abundant content of farmers' interest expression and deficiency of expression ability. In addition to the problem of land expropriation in new countryside construction mentioned above, farmers' interest expression also includes the content of the basic medical insurance, endowment insurance, infrastructure, service supply, etc. National long-term dual structure and the household registration system have a certain degree of alienation tendency to our rural development. As the core of national politics, economics, culture, city has the natural advantages and national policy support. Both in infrastructure and public resources are far superior to the countryside, the countryside seems to be a "corner" of the national machinery. [9] Although since China has put forward the aim of integration of urban and rural construction and the new rural construction, national finance prefers to the countryside to a certain extent, but farmers trapped into double troubles of power oppression and the actual living pressure result from poor implementation and vacuum phenomenon of regulatory constraints. Farmers' interest expression rich in content and closely relate to their own survival and development, furthermore, the development of farmers in turn affects our country to achieve the goal of all-round well-off society. Although the market economy development of our country has entered the stage of mature relatively, but farmers' residual feudalist idea limitations of the small peasant economy age still exist. The ability of its own interest expression is obvious insufficient, and lack of legal faith, additionally. There is no scientific idea guidance when appealing for proper interest, as a result, they lack of ability to participate in interest expression effectively. Farmers' group doesn't receive much education, and has been affected by the local centralized management mode for a long time, so it exists sharp contrast between abundance of expression content and deficiency of expression ability.

\section{Countermeasures to Perfect Mechanism Diploma of Farmers' Interest Expression in China}

According to the diploma and situation, countermeasures are mainly include two point of view. One is the national point of view, the other is social point of view. The former one embodies three parts.

First, Complete legal and regulatory system of farmers' interest expression. Law is the important means for normal operation of the national machine, and then makes some ambiguous political concept with legalization and rationalization through laws and regulations, when facing with similar problems in real life to follow the law. Perfect power operation system of organizations at the grass-roots level, the new rural construction is a significant project relates to farmers' interests. As the most basic interest expression mechanism, the grassroots organization should play a proper role to normalize its behavior through legal norm, and impose severe legal restraint when deal with unlawful actions. Power without restriction and supervision will be like a runaway horse to trample land institution, and then influence the construction of new socialist countryside, thus hinder farmers' interest expression channels. Establish a sound legal system to give legal restraint to executing loophole on the process of 
farmers' interest expression. Specify the relationship between subject and object of interest expression, and exercise compulsory measures to guarantee validity and feasibility of farmers' interest appeal.

Second, Boost institutional innovation of farmers' interest expression. At present, farmers' interest expression channels in our country are mainly embody political party system, letters and visits system, grass-roots mass self-government system, which are as the people's congress as core. Though the official channels exist in name, farmers own power of expression is not match to the expression system platform. Farmers cannot adapt to the existing institutional form of expression, there is a farmer's own reason, also has non-standard factors of the top system design. Build diversified expression corresponds to the farmers' expression ability, reform and innovate Chinese farmers' interest expression system, build a new system platform, improve the farmers speaking right appropriately, improve the system of letters and visits system, prevent normal farmers from being treated as "the mob" and "unruly", avoid the grassroots civil servants concealing facts, stopping up criticisms for the sake of obtaining private interests.

Third, Bring in governance model of deliberative democracy. Deliberative democracy is a new kind of interest expression, and plays a certain effect in our country's grassroots-level democracy management, so that the farmers can have equal dialogue with the government, express opinions freely. It is also a significant institutional arrangement in farmers' interest expression, which has a strong democratic potential, and can impact to imperative arrangements due to leadership type of oppression in the process of interest expression. Dealing with important decisions under negotiation of government and peasant when involves in farmers' own interest, such as holding democratic talkfest, public opinion hearings, listening to public opinion uphold the principle of fairness, and satisfying the desire of farmers to participate in the democratic management, reducing the policy execution hindrance, accumulating good political ecological resources, relieving tension state between officer and the public, promoting new countryside construction under the perspective of a harmonious society.

The Social Point of View Indicates two Requirements. First of all, give play to the role of mass media. As means of spreading news in Internet era, mass media has a powerful information dissemination way, and exposes the unreasonable behavior of society in time, which plays an important role in the aspect of social supervision and government accountability. Mass media's exposure of governmental behavior can bring some unknown inside information to public, which let farmers to get an effective and reliable platform to express their interest. The government had to compromise to provide farmers equal communication chance, promote the transparency of the government behavior in the construction of new countryside. But the mass media sometimes spreads gossip maliciously due to lack of modern ethics and the temptation of interest, so that to affect social stability, destroy social harmony, and bring about behaviors seriously influenced social public order. The government need to guide rationally and actively, standardize accountability of mass media correctly, and then provide them with freedom, at the same time with constraints, so that to build a responsible media.

Besides, integrate social capital and support farmers' self-governing organization. Social capital mainly refers to the influence, credibility and standardization of the construction of villagers' autonomous organization, these intangible factors have become important aspect of farmers' interest expression in the new countryside construction. Such as the grassroots autonomous organizations that represents the interests of the farmers is effected by the large national fiscal appropriations, and then become corrupt associated with local government, which has caused to the weakness of social capital power, farmers' interest expression channel is hindered. The political logic that dominates rural life has not been exist, the effectiveness of expressing interest is damaged in a way. Thus, government should carry out the integration of social capital, and support grass-roots autonomous organizations to manage local transactions themselves, additionally, reduce oppressive leadership from local governments to maintain basic living rights and interests appeal of farmers. [10] 


\section{Summary}

As the vulnerable class of our country, farmers' damage of interest in the process of new countryside construction is serious. The deficiency of necessary benefit expression mechanism leading to the frustration of modernization construction. Local governments and grass-roots staff is the direct executor to perform national will and carry out national policies, whose administrative behavior directly affect farmers' interest. The interest expression mechanism reflects the administrative level of local government. What's more, it is the fundamental right endowed by institution to guarantee farmers' spoken power sufficiently, and let farmers possess the chance to express themselves liberally, which is also the significant way to listen to public opinion and reflect the condition of the people to provide better service to the new countryside construction. Interest expression is thought to be the first step in the process of the government, whether the implementation of public policy, or the basic aspirations of citizens to express themselves, the expression of interest plays an irreplaceable role. Through the interest expression, government and citizens come into being a state of benign communication. Citizens have an effect on government public policy formulation through interest expression, so that government should listen to public opinion and reflect it in policy making to build a new socialist countryside.

\section{References}

[1] Chew Rosalind, Chew SOON-BENG, Union Social Responsibility: A Necessary Public Good in a Globalized World, International Journal of Comparative Labor Law\& Industrial Relations. Vol. 26(2010) No. 4, p.435-446.

[2] Rowley, Timothy I, Moldoveanu, Mihnea, Stakeholder Group Mobilization, Academy of Management Review. Vol. 28(2013) No. 02, p.204-219.

[3] Harrington, Catherine B, The Bush Administration's Gats Offer Supports Private Exoress Delivery Service But Threatens to Stamp out USPS, American University International Law Review. Vol. 19(2003) No.02, p. 431-483.

[4] Halbach Jr., Edward C, Future Interests: Express and Implied Conditions of Survival Part, California Law Review. Vol. 49(2006) No. 02, p.297.

[5] L. Yang, Y.J. Wu, the Countermeasure Study on Farmers' Interest Expression Mechanism in The Construction of New Countryside, Management Observer. Vol. 46(2015) No. 21, p.36-38.

[6] N.Y. Gao, The Establishment of Farmers' Interest Expression Mechanism under the Vision of New Countryside Construction, Humanities\& Social Sciences Journal of Hainan University, Vol. 12(2010) No. 01, p. 28-33.

[7] X.H. Hao, Construct New Countryside Must Perfect Farmers' Interest Expression Mechanism, New Heights, Vol. 6(2007) No.15, p. 79-81.

[8] S.Z. Yan and P. Hong, The New Rural Construction under The Horizon of Farmers' Main Body Status, Business Management, Vol. 17(2013) No. 05, p. 7-10.

[9] S.H. Lan, Perfect Expression Mechanism of Farmers' Interest, Journal of Socialist Theory Guide, Vol. 16 (2009) No.03, p. 59-61.

[10]M.L. Hu and J.H. Xiao, How to Express Farmers' Interest in The Construction of New Countryside, Seeker, Vol. 14(2007) No. 04, p. 64-65. 